\author{
Celebes Education Review \\ http://journal.lldikti9.id/CER/index \\ Volume 2, No, 1, April 2020 \\ p-ISSN: 2656-7385 dan e-ISSN: 2684-7124
}

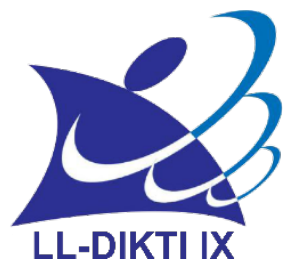

\title{
Meningkatkan Hasil Belajar Matematika Melalui Pendekatan Pemecahan Masalah dengan Strategi Polya Pada Siswa Kelas XI IPA SMA Negeri 2 Kalukku
}

\author{
Sudirman ${ }^{\mathbf{1}}$ \\ 1 SMAN 2 Mamuju, Sulawesi Barat \\ Email:dirmanmamuju@yahoo.com
}

\section{Artikel info}

Artikel history:

Received; 14-03-

2020

Revised:26-03-

2020

Accepted;28-03-

2020
Abstrak: Penelitian ini adalah penelitian tindakan kelas yang bertujuan untuk mendeskripsikan (1) peningkatan hasil belajar Matematika melalui pendekatan pemecahan masalah dengan strategi Polya siswa kelas XI IPA di SMAN 2 Kalukku, (2) peningkatan keterampilan pemecahan masalah Matematika dengan strategi Polya . Subjek penelitian adalah siswa kelas XI IPA SMAN 2 Kalukku, sebanyak 31 orang terdiri dari 11 siswa laki-laki dan 20 siswa perempuan. Teknik yang digunakan untuk menganalisis data adalah analisis kualitatif dan kuantitatif. Data kualitatif digunakan pada aktivitas siswa sedangkan data kuantitatif digunakan pada prestasi belajar siswa dan respons siswa. Hasil penelitian menunjukkan bahwa (1) penerapan pendekatan pemecahan masalah dengan strategi Polya dapat meningkatkan prestasi belajar siswa pada Matematika ditunjukkan oleh analisis deskriptif dari skor rata-rata prestasi belajar siswa 65,42 pada siklus I hingga 75,06 pada siklus II; (2) penerapan pendekatan pemecahan masalah dengan strategi Polya dapat meningkatkan keterampilan pemecahan masalah siswa pada Matematika ditunjukkan dengan analisis deskriptif persentase, yaitu tahap pemahaman masalah $83,87 \%$ pada siklus I hingga $90,32 \%$ pada siklus II, tahap perencanaan pemecahan masalah $87,10 \%$ pada siklus I hingga $96,77 \%$ pada siklus II, implementasi tahap perencanaan penyelesaian masalah $90,32 \%$ pada siklus I menjadi $98,77 \%$ pada siklus II, dan tahap pengecekan kembali $38,71 \%$ pada siklus I hingga $70,97 \%$ pada siklus II.

Abstract; The study is a classroom action research which aims at describing (1) the improvement of Mathematics learning result through problem solving approach by Polya strategy of class XI IPA students at SMAN 2 Kalukku, (2) the improvement of Mathematics problem solving skill by Polya strategy. The subject is students of class XI IPA of SMAN 2 Kalukku, as many as 31 people consisted of 11 male and 20 female students. The technique used to analyze the data is qualitative and quantitative analyses. The qualitative data is used on students' activities while the quantitative data is used on students' learning achievement and students' response. The results indicate that (1) the application of problem solving approach by Polya strategy can improve students' learning achievement on Mathematics indicated by the descriptive analysis of the average score of students' learning achievement 65.42 at cycle I to 75.06 at cycle II; (2) the application of problem solving approach by Polya strategy can improve students' problem solving skill on Mathematics indicated by percentage descriptive analysis, which is problem comprehension stage $83.87 \%$ at cycle I to $90.32 \%$ at cycle II, problem solving planning stage $87.10 \%$ at cycle I to $96.77 \%$ at cycle II, the implementation of problem solving planning stage $90.32 \%$ at cycle I to $98.77 \%$ at cycle II, and rechecking stage $38.71 \%$ at cycle I to $70.97 \%$ at cycle II. 


$\begin{aligned} & \text { Keywords: } \\ & \text { hasil belajar, }\end{aligned}$
$\begin{aligned} & \text { matematika, } \\ & \text { pendekatan } \\ & \text { polya, }\end{aligned}$
$\begin{aligned} & \text { pemecahan } \\ & \text { masalah }\end{aligned}$

\section{PENDAHULUAN}

Pemecahan masalah adalah bagian dari kurikulum matematika yang sangat penting karena dalam proses pembelajaran maupun penyelesaian, siswa dimungkinkan memperoleh pengalaman menggunakan pengetahuan serta keterampilan yang sudah dimiliki untuk diterapkan pada pemecahan masalah. Kenyataan dilapangan menunjukkan bahwa kegiatan pemecahan masalah dalam proses pembelajaran matematika belum dijadikan sebagai kegiatan utama (Suherman, 2001:83).

Upaya mengatasi isu pembelajaran matematika senantiasa dilakukan para pemerhati dan pengguna matematika. Perbaikan dilakukan dengan lebih mempertimbangkan berbagai pandangan atau filsafat pembelajaran yang mutakhir, seperti bergesernya pandangan belajar dari teacher center ke student center atau lebih memfokuskan pada pandangan perkembangan mental (development mental) yang mengutamakan proses dengan tidak mengesampingkan pandangan tingkah laku (behavioristik) yang mengutamakan produk (Anonim, 2008).

Rendahnya hasil belajar matematika bukan hanya disebabkan karena matematika yang sulit dan tidak menyenangkan, melainkan disebabkan oleh beberapa faktor. Menurut Slameto (2003:54) terdapat dua faktor yang dapat mempengaruhi hasil belajar siswa yakni faktor interen dan faktor eksteren. Salah satu faktor interen adalah keadaan siswa itu sendiri dalam hal ini adalah kesehatan, intelegensi, bakat, motivasi dan kesiapan memperoleh pelajaran. Sedangkan, faktor eksteren adalah ekonomi keluarga, kurikulum sekolah dan yang terpenting adalah guru. Disamping itu lingkungan belajar yang buruk akan sangat mempengaruhi rendahnya hasil belajar siswa, khususnya matematika. Selain itu, faktor lain yang dapat mempengaruhi rendahnya hasil belajar siswa adalah adanya anggapan atau asumsi yang keliru dari sebagian guru yang menganggap bahwa pengetahuan itu dapat dipindahkan secara utuh dari pikiran guru ke pikiran siswa.

Observasi awal yang penulis lakukan di kelas XI IPA SMA Negeri 2 Kalukku menunjukkan bahwa siswa memiliki kemampuan untuk memecahkan masalah matematika masih rendah sehingga hasil belajar matematika rendah. Hal ini disebabkan mereka kurang aktif melibatkan diri dalam mengerjakan tugas-tugas yang dapat membangun kemampuan berpikir mereka untuk memecahkan masalah matematika yang sedang dihadapi.

Dengan mengkaji kenyataan yang ditemukan di lapangan, wawancara dengan guru matematika, nampaknya ada ketidaksesuaian antara proses pembelajaran dengan pendekatan yang digunakan. Proses pembelajaran yang biasa dilakukan oleh guru selama ini hanya mampu menggambarkan aspek penguasaan konsep peserta didik, akibatnya tujuan kurikuler mata pelajaran matematika belum dapat dicapai secara menyeluruh. Untuk itu perlu diupayakan suatu teknik pembelajaran yang mampu mengungkap aspek produk maupun proses.

Hal tersebut di atas, mengarahkan pada kesimpulan bahwa diperlukan sebuah pendekatan pembelajaran yang lebih memberdayakan siswa, melibatkan siswa secara aktif, yang tidak mengharuskan siswa menghafal fakta-fakta, tetapi pendekatan yang mendorong siswa mengkonstruksikan pengetahuan dibenak mereka sendiri agar pengaruhnya terhadap 
kemampuan berpikir analisis dan kemampuan memecahkan masalah matematika maupun masalah dalam kehidupan sehari-hari lebih terstruktur dan terpola.

Penelitian ini bertujuan untuk (1) mendeskripsikan meningkatkan hasil belajar matematika melalui penerapan pendekatan pemecahan masalah dengan strategi Polya, (2) mendeskripsikan meningkatkan kemampuan pemecahan masalah matematika dengan strategi Polya.

\section{Metode Penelitian}

Penelitian ini adalah penelitian tindakan kelas (classroom action research), sebagaimana paradigma penelitian tindakan kelas yang meliputi: perencanaan (planning), tindakan (acting), observasi (observating) atau evaluasi (evaluating), dan refleksi (reflecting) yang bersiklus. Lokasi pada penelitian ini dilaksanakan di SMA Negeri 2 Kalukku, Kabupaten Mamuju, Provinsi Sulawesi Barat. Subjek penelitian adalah siswa kelas XI IPA SMA Negeri 2 Kalukku, Kabupaten Mamuju, Provinsi Sulawesi Barat, tahun pelajaran 2013/2014 semester 2, sebanyak 31 orang yang terdiri atas 11 laki-laki dan 20 perempuan. Penelitian ini dilaksanakan dalam dua siklus, dan masing-masing siklus terdiri atas empat kali pertemuan, dengan maksud untuk mengetahui perkembangan perubahan pelaksanaan proses pembelajaran dan dapat melakukan tahapan perbaikan dengan baik. Masing-masing siklus memiliki 4 tahap, yaitu tahap perencanaan (planning), pelaksanaan tindakan (acting), observasi (observating) atau evaluasi (evaluating) dan refleksi (reflecting). Kegiatan ini dilaksanakan secara kolaborasi partisipatif antara guru bidang studi dengan peneliti. Guru berperan sebagai observer dan peneliti sebagai pembelajar. Sebelum melakukan penelitian, peneliti melakukan observasi di sekolah yang bersangkutan, khususnya tentang pelaksanaan pembelajaran matematika.

Tahapan-tahapan yang dilakukan dalam penelitian siklus 1 ini adalah sebagai berikut: a. Tahap perencanaan (planning). Adapun kegiatan yang dilakukan dalam tahap perencanaan adalah sebagai berikut:

a. Menelaah kurikulum SMA Negeri 2 Kalukku Kelas XI IPA semester 2 tahun pelajaran 2013/2014.

1. Membuat Rencana Pelaksanaan Pembelajaran (RPP) dengan pendekatan pemecahan masalah dengan strategi Polya untuk materi fungsi komposisi.

2. Menyusun Lembar Kerja Siswa (LKS)

3. Membuat alat evaluasi, untuk mengukur pencapaian hasil belajar siswa yang dilaksanakan pada setiap akhir siklus.

b. Tahap pelaksanaan tindakan (acting).Adapun langkah-langkah yang dilakukan pada tahap ini, antara lain sebagai berikut.

1. Melaksanakan kegiatan proses pembelajaran sesuai dengan RPP yang telah dibuat, dan pada pertemuan awal disampaikan kepada siswa mengenai pendekatan pembelajaran yang akan digunakan.

2. Pada saat kegiatan proses pembelajaran berlangsung, dilakukan observasi dengan menggunakan pedoman observasi yang telah disiapkan.

3. Pada akhir siklus I, siswa diberikan tes hasil belajar.

4. Siswa diminta menyampaikan respons terhadap kegiatan pembelajaran yang telah dilaksanakan sepanjang siklus I, dengan mengisi angket respons siswa yang telah disediakan.

c. Tahap observasi (observating) atau evaluasi (evaluating)

Selama kegiatan pembelajaran berlangsung, dilakukan observasi. Dalam kegiatan ini, guru (peneliti) dibantu seorang observer (pengamat). Hal-hal yang diamati, antara lain sebagai berikut. 
1. Aktivitas guru dalam mengelola atau melaksanakan kegiatan pembelajaran.

2. Aktivitas siswa dalam mengikuti kegiatan proses pembelajaran.

3. Pemahaman siswa terhadap materi pelajaran selama berlangsungnya kegiatan proses pembelajaran, dengan melihat kemampuan siswa dalam menyelesaikan masalah.

4. Kemampuan siswa dalam menyelesaikan masalah matematika diambil berdasarkan kuis yang telah diberikan.

5. Respons siswa terhadap proses pembelajaran yang dilaksanakan oleh guru.

d. Tahap refleksi (reflecting)

Data yang diperoleh pada tahap observasi dikumpulkan dan di analisis, baik secara kuantitatif maupun kualitatif, yang meliputi data hasil observasi aktivitas siswa, data kemampuan guru mengelola pembelajaran, data hasil belajar siswa, dan data mengenai respons siswa. Hasil observasi dianalisis untuk dijadikan bahan pemikiran dalam merefleksi kegiatan selama tindakan dilakukan. Pada tahap ini dilihat sampai dimana faktor-faktor yang diselidiki telah tercapai. Hal-hal yang masih kurang atau kelemahan-kelemahan yang didapat, menjadi catatan untuk diperbaiki dan yang sudah baik dapat dikembangkan dan dipertahankan pada siklus berikutnya.

\section{Siklus 2}

a. Tahap perencanaan (planning)

Adapun kegiatan yang dilakukan dalam tahap perencanaan adalah sebagai berikut:

1. Menelaah kembali Rencana Pelaksanaan Pembelajaran (RPP) agar sesuai dengan pendekatan pemecahan masalah dengan strategi Polya pada materi fungsi invers .

2. Menelaah kembali Lembar Kerja Siswa (LKS)

3. Menyiapkan alat evaluasi, untuk mengukur pencapaian hasil belajar siswa yang dilaksanakan pada setiap akhir siklus. b. Tahap pelaksanaan tindakan (acting)

Adapun langkah-langkah yang dilakukan pada tahap ini, antara lain sebagai berikut.

1. Melaksanakan kegiatan proses pembelajaran sesuai dengan RPP yang telah disempurnakan.

2. Pada saat kegiatan proses pembelajaran berlangsung, dilakukan observasi dengan menggunakan pedoman observasi yang telah disiapkan.

3. Pada akhir siklus II, siswa diberikan tes hasil belajar.

c. Tahap observasi (observating) atau evaluasi (evaluating)

Selama kegiatan pembelajaran berlangsung, dilakukan obsevasi. Dalam kegiatan ini, guru (peneliti) dibantu oleh seorang observer (pengamat). Hal-hal yang diamati, antara lain sebagai berikut.

1. Kemampuan siswa dalam menyelesaikan masalah matematika berdasarkan kuis yang telah diberikan.

2. Respons siswa terhadap proses pembelajaran yang dilaksanakan oleh guru.

d. Tahap refleksi (reflecting)

Data yang diperoleh pada tahap observasi dikumpulkan dan analisis, baik secara kuantitatif maupun kualitatif, yang meliputi data hasil observasi aktivitas siswa, data kemampuan guru mengelola pembelajaran, data hasil belajar, dan data mengenai respons siswa. Hasil observasi dianalisis untuk dijadikan bahan pemikiran dalam merefleksi kegiatan selama tindakan dilakukan. Pada tahap ini dilihat sampai dimana faktor-faktor yang diselidiki telah tercapai. Sehingga hasil yang dicapai pada siklus ini sesuai dengan yang diharapkan, yaitu lebih baik dari siklus sebelumnya. 


\section{Hasil Penelitian dan Pembahasan}

Jadwal kegiatan pelaksanaan siklus I ditetapkan 4 kali pertemuan. Pertemuan pertama membahas aturan fungsi komposisi. Pertemuan kedua membahas nilai fungsi komposisi terhadap komponen pembentuknya. Pertemuan ketiga komponen fungsi komposisi bila aturan komposisinya diketahui. Pertemuan keempat mengajarkan sifat-sifat fungsi komposisi. Semua kegiatan akan diimplementasikan dalam pembelajaran berdasarkan. Tahap tindakan dalam siklus pertama selama empat kali pertemuan diimplementasikan dalam RPP (Lampiran 1). Berdasarkan RPP impelementasi tindakan pada semua pertemuan meliputi: pendahuluan, kegiatan inti, dan kegiatan penutup. Berdasarkan pelaksanaan tindakan pada siklus I melalui pembelajaran dengan pendekatan pemecahan masalah dengan strategi Polya pada siswa kelas XI IPA SMA Negeri 2 Kalukku skor kuis kemampuan siswa memecahkan masalah matematika menurut langkah-langkah Polya, terletak pada kategori tinggi untuk kemampuan memahami masalah matematika $(83,87 \%)$, merencanakan pemecahan masalah matematika $(87,10 \%)$, dan melaksanakan perencanaan pemecahan masalah matematika $(90,32 \%)$ dan kemampuan mengecek kembali proses dan hasil perencanaan masalah matematika berada pada kategori sangat rendah $(38,71 \%)$.

Walaupun hasil kemampuan pemecahan masalah matematika siswa telah menunjukkan ketuntasan secara klasikal tetapi kemampuan siswa pada tahap mengecek kembali proses dan hasil penyelesian memerlukan perhatian khusus. Selama pelaksanaan siklus I ada beberapa kendala yang dihadapi peneliti antara lain siswa masih bingung tentang pendekatan pemecahan masalah dengan strategi Polya yang digunakan karena mereka masih terbiasa dengan pendekatan yang selama ini diterapkan. Belum terbiasanya siswa menyelesaikan soalsoal yang ada dalam Lembar Kuis Siswa karena harus mengikuti langkah- langkah Polya. Waktu yang tertera dalam Lembar Kuis Siswa masih dirasa kurang oleh siswa sehingga masih ada siswa yang belum menyelesaikan soal-soal tepat waktu. Kekurangan pada siklus I dapat dijadikan acuan untuk memperbaiki pelaksanaan tindakan pada siklus II dan keberhasilan pada siklus I dapat dipertahankan dan dikembangkan untuk mencapai keberhasilan sesuai dengan langkah yang telah ditetapkan pada siklus II.

Jadwal pelaksanaan kegiatan siklus II ditetapkan 4 kali pertemuan. Pertemuan pertama membahas syarat suatu fungsi memiliki fungsi invers. Pertemuan kedua membahas cara menentukan rumus fungsi invers. Pertemuan ketiga membahas cara menentukan fungsi invers dari fungsi komposisi. Pertemuan keempat membahas cara menentukan fungsi invers dari fungsi komposisi. Semua kegiatan pembelajaran akan diimplementasikan berdasarkan RPP. Berdasarkan pelaksanaan tindakan pada siklus II proses pembelajaran dengan penerapan pendekatan pemecahan masalah dengan strategi Polya pada siswa kelas XI IPA SMA Negeri 2 Kalukku skor kemampuan siswa memecahkan masalah matematika menurut langkahlangkah Polya terletak pada kategori sangat tinggi (kemampuan memahami masalah matematika 90,32\%, merencanakan pemecahan masalah matematika 96,77\%, dan melaksanakan perencanaan pemecahan masalah matematika 96,77\% dan kemampuan mengecek kembali proses dan hasil perencanaan masalah matematika berada pada kategori sedang $70,79 \%$ ).

\section{Pembahasan}

Kemampuan pemecahan masalah matematika menurut Polya, pelaksanaan proses pembelajaran pada siklus I sebanyak empat kali pertemuan, nampak bahwa siswa masih mengalami kesulitan dalam memecahkan masalah matematika menurut langkah-langkah Polya terutama pada kemampuan mengecek kembali proses dan hasil pelaksanaan 
perencanaan masih tergolong rendah. Adapun deskripsi kemampuan pemecahan masalah matematika menurut langkah-langkah Polya pada siklus I adalah sebagai berikut: pada pertemuan pertama, terlihat bahwa masih ada siswa yang belum memahami masalah matematika, yaitu sekitar 54,83\%, berada pada tingkat kemampuan rendah. Pada pertemuan selanjutnya terjadi meningkatkan siswa yang mampu memahami masalah, bahkan pertemuan terakhir $82,26 \%$ siswa sudah mampu dan dapat memahami masalah metamatika dan berada pada tingkat kemampuan tinggi ,kemampuan siswa merencanakan pemecahan masalah matematika, bahwa siswa yang sudah mampu merencanakan pemecahan masalah matematika, yaitu sekitar 54,84\% dari jumlah siswa yang hadir, berada pada tingkat kemampuan rendah. Disebabkan kurangnya perhatian siswa terhadap materi yang diberikan. Sedangkan pada pertemuan selanjutnya terjadi meningkatkan siswa yang kurang mampu merencanakan pemecahan masalah matematika yang diberikan pada akhir pertemuan siklus I yaitu pertemuan keempat siswa yang dapat merencanakan pemecahan masalah matematika meningkat sampai $82,26 \%$ berada pada tingkat kemampuan tinggi. Kemampuan siswa melaksanakan rencana penyelesaian pada pertemuan pertama siklus I, hanya sebagian siswa saja yang mampu melaksanakan rencana penyelesaian, yaitu sekitar 57,26\% yang mampu melaksanakan rencana penyelesaian masalah matematika. Tetapi pada pertemuan terakhir yaitu pertemuan keempat mengalami meningkatkan, yaitu sekitar 83,06\% dari jumlah siswa yang hadir yang mampu melaksanakan rencana penyelesaian masalah matematika. Kemampuan siswa mengecek kembali proses dan hasil penyelesaian, pada pertemuan pertama terlihat bahwa masih kurang siswa yang mampu mengecek kembali proses dan hasil penyelesaian masalah matematika yaitu sekitar $45,09 \%$ dan selanjutnya pada pertemuan keempat yaitu sekitar 78,55\% yang mampu mengecek kembali proses dan hasil penyelesaian masalah matematika.

Kemampuan pemecahan masalah matematika menurut Polya pada siklus II, penerapan pembelajaran melalui pendekatan pemacahan masalah dengan startegi Polya pada awal pertemuan siswa dituntun menyelesaikan masalah sesuai dengan langkah-langkah pemecahan masalah menurut Polya. Pada pertemuan pertama sampai pertemuan keempat untuk siklus II, siswa sudah mulai memahami langkah-langkah penyelesaian menurut Polya. Kemampuan siswa memecahkan masalah matematika sudah mulai ada meningkatkan. Hal ini dapat dilihat dari frekuensi siswa yang memecahkan masalah matematika yang diberikan meningkat pada tiap pertemuan. Kemampuan siswa memecahkan masalah matematika pada siklus II berada pada tingkat kemampuan tinggi. Adapun deskripsi kemampuan pemecahan masalah matematika menurut langkah-langkah Polya pada siklus II adalah sebagai berikut: (1) kemampuan siswa memahami masalah matematika, pada pertemuan pertama, terlihat bahwa ada perubahan kemampuan siswa memahami masalah matematika yaitu 69,35\%. Pada pertemuan selanjutnya terjadi perubahan siswa yang mampu memahami masalah matematika, bahkan pertemuan terakhir $88,71 \%$ siswa sudah mampu memahami masalah metamatika dan berada pada tingkat kemampuan tinggi, (2) kemampuan siswa merencanakan pemecahan masalah matematika, pada pertemuan pertama, terlihat bahwa sekitar 58,06\% siswa yang hadir mampu merencanakan pemecahan masalah matematika dan pada pertemuan berikutnya terjadi meningkatkan terus menerus bahkan pada pertemuan keempat siklus II, siswa yang dapat merencanakan suatu penyelesaian masalah matematika meningkat 86,29\% berada dalam kategori tinggi, (3) kemampuan siswa melaksanakan rencana penyelesaian, pada pertemuan pertama siklus II, yaitu sekitar 59,68\% yang mampu melaksanakan rencana penyelesaian masalah matematika sedangkan pada pertemuan berikutnya mengalami meningkatkan siswa yang mampu melaksanakan rencana penyelesaian masalah matematika yaitu $85,48 \%$ berada pada kategori tinggi, dan (4) kemampuan siswa mengecek kembali proses dan hasil penyelesaian, pada pertemuan pertama siklus II siswa yang mengecek 
kembali proses dan hasil penyelesaiannya yaitu 49,38 mengalami meningkatkan sampai pertemuan keempat yaitu $80,71 \%$ berada pada kategori tinggi.

Sejalan dengan hasil penelitian oleh Capper (1984) mengemukakan bahwa pengalaman siswa sebelumnya, perkembangan kognitif, serta minat (ketertarikannya) terhadap matematika merupakan faktor-faktor yang sangat berpengaruh terhadap keberhasilan dalam pemecahan masalah. Senada dengan hasil penelitian yang dilakukan The National Assessment of Educational Progress (NAEP) (dalam Kouba et. Al., 1988) menunjukkan bahwa siswa kelas tiga memperoleh prestasi baik dalam soal setting yang dikenal siswa. Sekitar $90 \%$ siswa berhasil dengan baik menyelesaikan soal pemecahan masalah yang memuat penjumlahan bilangan bulat dengan satu langkah penyelesaian, dan $70 \%$ dari mereka berhasil dengan baik menyelesaikan soal yang memuat pengurangan dengan satu langkah penyelesaian. Dalam soal pemecahan masalah dengan dua langkah penyelesaian, prestasi mereka kurang begitu baik. Sekitar 30\% siswa kelas tiga berhasil dengan baik menyelesaikan soal pemecahan masalah yang memuat penjumlahan atau pengurangan dengan dua langkah penyelesaian, sedangkan $77 \%$ siswa kelas tujuh dapat menyelesaikan dengan baik jenis soal yang sama.

Hasil belajar siswa, menurut Sudjana (2001:22) berpendapat bahwa "hasil belajar adalah kemampuan-kemampuan yang dimiliki oleh siswa setelah ia menerima pengalaman belajarnya". Hasil belajar matematika adalah kemampuan yang dicapai siswa setelah mengikuti proses belajar mengajar yang diperoleh melalui pemberian tes hasil belajar. Sejalan dengan apa yang dikemukakan di atas, maka hasil belajar siswa setelah diberikan tindakan pada siklus I dan siklus II dengan penerapan pendekatan pemecahan masalah dengan strategi Polya mengalami MENINGKATKAN yaitu rata-rata hasil belajar siswa 65,42 siklus I menjadi 75,06 siklus II, ketuntasan belajar siswa secara klasikal adalah 87,10\% siklus I dan 93,54\% siklus II (Tabel 2).

\section{Simpulan dan Saran}

1. Hasil belajar siswa mengalami peningkatan setelah diterapkan pendekatan pemecahan masalah dengan strategi Polya yaitu: skor rata-rata 65,42 siklus I menjadi 75,06 siklus II dan hasil belajar siswa mencapai ketuntasan klasikal yaitu 90,32\% (ketuntasan klasikal $\geq 85 \%$ ).

2. Kemampuan siswa memecahkan masalah matematika menurut langkah-langkah Polya mengalami peningkatan yaitu kategori memahami masalah dari $83,87 \%$ siklus I menjadi $90,32 \%$ siklus II, merencanakan penyelesaian masalah dari $87,10 \%$ siklus I menjadi 96,77\% siklus II, melaksanakan rencana penyelesaian masalah dari 90,32\% siklus I menjadi 98,77\% siklus II, dan mengecek kembali proses dan hasil dari 38,71\% siklus I menjadi 70,97\% siklus II

\section{Saran}

1. Untuk meningkatan kemampuan pemecahan masalah matematika bagi siswa maka disarankan supaya menerapkan pendekatan pemecahan masalah dengan strategi Polya dalam pembelajaran matematika.

2. Untuk meningkatkan keterampilan proses siswa maka perlu kiranya siswa dibiasakan untuk terus berlatih mengerjakan tugas dalam memecahkan masalah matematika dengan mengikuti langkah-langkah Polya.

3. Untuk meningkatkan hasil belajar siswa, maka direkomendasikan agar guru dapat menerapkan pendekatan pemecahan masalah dengan strategi Polya. 
4. Penelitian ini dapat dilanjutkan oleh peneliti lain yang berminat dengan mengambil subjek penelitian yang berbeda, sehingga hasil yang diharapkan bisa lebih baik.

\section{Daftar Pustaka}

Arikunto, Suharsimi. 2003. Penelitian Laporan PTK. Jakarta: Depdiknas.

Ausubel, D.P. 1968. Educational Psychology: A Cognitive View. New York: Holt Rienhart and Winston.

Bell, F.H. 1978. Teaching and Learning Mathematics. (Un Secondary School). Iowa Wm. C. Brown Company Publishers.

Branca, N. A. 1980. Problem Solving as a Goal, Process and Basic Skill. Dalam Krulik,S dan Reys,R.E (ed). Problem Solving in School Mathematics. NCTM: Reston. Virginia

Bruner, J. 1977. The Process of Education. Cambridge: Harvard University Press.

Departemen Pendidikan Nasional. 2003a. Kurikulum 2004 Standar Kompetensi Matematika SMA dan MA. Jakarta: Depdiknas.

Dimyanti dan Mudjiono. 1994. Belajar dan Pembelajaran. Jakarta: P3MTK-Ditjen DiktiDepdikbud.

Djadir. 2005. "Studi Eksplorasi Keterlaksanaan Pembelajaran Matematika dengan

Menggunakan Model Kooperatif Tipe STAD di SMP”. Makassar: Jurnal Ilmu

Pendidikan Volume 2 Nomor 1, Mei 2005 LPMP Sulawesi Selatan.

English, L.D. 1998. Children's Problem Posing Formal and Informal Contexts. Journal for Research in Mathematics Education. 29(1).83-106.

Hudojo, Herman. 1979. Pengembangan Kurikulum Matematika dan Pelaksanaannya di

Depan Kelas. Surabaya: Usaha Nasional.

Krismanto. 2003. Beberapa Teknik, Model, dan Strategi dalam Pembelajaran Matematika. Yogyakarta: PPPG Matematika.

Muhammad Darwis, 2007. Model Pembelajaran Matematika yang Melibatkan Kecerdasan

Emosional. Disertasi Tidak Diterbitkan. Surabaya: Universitas Negeri Surabaya. NCTM, 2000. Principles and Standards for School Mathematics. Reston: VA.Author.

Nurdin, 2007. Model Pembelajaran Matematika yang Menumbuhkan Kemampuan Metakognitif untuk Menguasai Bahan Ajar. Universitas Negeri Surabaya. Disertasi. Tidak diterbitkan. Surabaya: PPs Unair.

Piaget, J. 1971. Psychology and Epistemology. New York: The Viking Press.

Polya, George. 1985. How to Solve It . A New Aspect of Mathematical Method (2 $2^{\text {nd }} \mathrm{ed}$ ).

Princeton, New Jersey : Princeton University Press.

Sabandar, Jozua. 2009. Matematika SMA/MA Kelas XI Program IPA. Jakarta: PT. Bumi Aksara.

Slameto. 2003. Belajar dan Faktor-Faktor yang Mempengaruhinya. Jakarta: Rineka Cipta Soedjadi, R. 1995. Mis-Konsepsi Dalam Pengajaran Matematika. (Pokok-Pokok Tinjauan Dikaitkan dengan Konstruktivisme). Surabaya: Media Pendidikan IKIP Surabaya.

Sugiman. 2000. Konstruktivisme Melalui Pendekatan Realistik dalam Pengajaran Matematika. Pengembangan Pendidikan MIPA di Era Globalisasi. hlm 165 - 170.

Suherman, 2001. Strategi Pembelajaran Matemtika. Bandung JIC. UPI

Sudjana, Nana. 2001. Penilaian Hasil Proses Belajar Mengajar. Bandung: Remaja Rosdakarya 